\title{
EFFECTIVENESS OF ENTREPRENEURIAL UNIVERSITIES: EXPERIENCES AND CHALLENGES IN DIGITAL ERA (A SYSTEMIC APPROACH)
}

\author{
Gandolfo Dominici ${ }^{1, *}$ and Ineza Gagnidze ${ }^{2}$
}

\author{
${ }^{1}$ University of Palermo \\ Palermo, Italy \\ ${ }^{2}$ Ivane Javakhishvili Tbilisi State University \\ Tbilisi, Georgia
}

DOI: $10.7906 /$ indecs.19.1.2

Received: 24 November 2019.

Regular article

Accepted: 15 January 2021.

\begin{abstract}
The modern world actively discusses the challenges that will lead to the Fourth Industrial Revolution. As the specialists assume, part of the jobs will be replaced by artificial intelligence. In addition, creation of completely new jobs is expected. As for the jobs that might be maintained in future, skills upgrading will be particularly important.

In such a turbulent environment of economic development, universities, and in particular entrepreneurial universities, play a significant role. We think so as these universities have special structures that promote form a university-industry-government triple helix, reskilling and commercialization of new ideas, etc. Due to the above-mentioned factors, they will neutralize the expected fluctuations in the best way. Later we will discuss the systemic links between the mutual influence of entrepreneurial universities and economy. We consider that continuous connection with such universities will enable business to adapt to the inevitable changes with minimal loss.
\end{abstract}

\section{KEYWORDS}

fourth industrial revolution, future of jobs, entrepreneurial university, triple helix, spin-offs, system, innovative development, patents, education system, entrepreneurial ecosystem

\section{CLASSIFICATION}

JEL: $\quad$ I23

*Corresponding author: $\eta$ : gandolfo.dominici@libero.it; -; - 


\section{INTRODUCTION}

Since 2016 the World Economic Forum published several reports, where the main issues were connected with the Fourth Industrial Revolution. "With the 4IR, humanity has entered a new phase. The 4IR has become the lived reality for millions of people around the world, and is creating new opportunities for business, government and individuals" [1].

So facts relevant to this approach are as follows:

- "Across all industries, by 2022, growth in emerging professions is set to increase their share of employment from $16 \%$ to $27 \%$ (11\% growth) of the total employee base of company respondents, whereas the employment share of declining roles is set to decrease from currently $31 \%$ to $21 \%$ (10\% decline)" [2];

- "An estimates suggest that at least $54 \%$ of all employees will require reskilling and upskilling by 2022 . Of these, over a third will require more than six months of additional training. However, only around $30 \%$ of employees in the jobs most exposed to technological disruption received any kind of training in the past year" [3];

- "In many industries and countries, the most in-demand occupations or specialties did not exist 10 or even five years ago, and the pace of change is set to accelerate. By one popular estimate, $65 \%$ of children entering primary school today will ultimately end up working in completely new job types that don't yet exist" [4];

- "The workforce transitions ahead will be enormous ... as many as 375 million workers globally (14\% of the global workforce) will likely need to transition to new occupational categories and learn new skills, in the event of rapid automation adoption. If their transition to new jobs is slow, unemployment could rise and dampen wage growth" [5]

- The global unemployment rate could rise to 24 percent (or more) in the year 2050. If we do nothing or nothing fundamental to adapt to the new realities of work, the social gap will continue to widen" [6];

- "As higher education leaders and policymakers think about how to prepare for the future of work, the educational system must be at the crux of any solution" [7].

The above-mentioned facts put on the agenda the necessity of finding the tools, which can be used to mitigate the potential challenges and apply to new opportunities. We consider entrepreneurial universities as one of these tools.

Universities have gone through several stages of development to reach their present state, with their roles and missions changing. In the late twentieth century, the term 'entrepreneurial university' appeared in the academic literature to describe universities that have improved various mechanisms by developing their local economy and increasing their incomes.

This article deals with the literature on entrepreneurial universities, discusses the role of the entrepreneurial universities in formation of an entrepreneurial ecosystem, analyzes the role of the universities in overcoming the challenges of the Fourth Industrial Revolution. Finally, the article schematically illustrates the systemic role of the entrepreneurial university for the development of the local economy.

\section{METHODOLOGY}

In preparing this article, we reviewed the literature on entrepreneurial universities, studied reports and reviews by international organizations and by recognized research centers (such as 
European Commission, the World Economic Forum, the OECD, McKinsey Global Institute, the University Industry Innovation Network (UIIN), European Expert Network on Economics of Education (EENEE), the Global Entrepreneurship and Development Institute - GEDI (USA), and others). The findings relate to the economies of both developed countries and developing countries.

In addition to this, literature review on entrepreneurial universities was done in two directions, in particular:

1. The literature that deal with the experience of two and more countries in the activities of entrepreneurial universities;

2. The literature that analyze the case of one university in different countries.

In studying, entrepreneurial universities one of the main methods to compare, both in time (considering research conducted on universities over several years) and in space (considering research focusing one country, on a few countries, or throughout the World). Surveys were analyzed in detail to create a clear picture of the research topic.

The investigation of entrepreneurial universities is based on the views of many authors. To test the hypotheses, we employ synthesis, analogy, description and correlation methods, as well as a systemic approach. To help the reader become acquainted with the opinions expressed in the article, we present schemes developed by ourselves and other authors. We have adopted a system that reflects the interaction and interdependence between economy and entrepreneurial universities.

To explore the topic expressed in the title of the article, we put forward a research question: are the entrepreneurial universities effective for the innovative development in the digital era?

\section{ENTREPRENEURIAL UNIVERSITY: A BRIEF LITERATURE REVIEW}

At the end of the $20^{\text {th }}$ century, a new term "entrepreneurial university" appeared in the scientific literature to describe universities that have improved various mechanisms to promote regional development and increase their incomes. Additionally, other terms used have been: University Technological Transfer, Innovative Universities, Business Universities and Market Universities. "The transformation of the university system is a worldwide phenomenon" [8]. "One significant European response is seen in the development, in concept and in practice, of the "Entrepreneurial University". To find a single definition of the Entrepreneurial University which works across the European Higher Education Area is difficult and controversial" [9]. The characteristics of entrepreneurial universities are described interestingly by several authors [10-22].

In the article we shall try to analyze the scientific literature referring to the experience of different countries on entrepreneurial universities in several directions, namely:

1. The reports and reviews by international organizations and recognized research centers;

2. The literature that deal with the experience of two and more countries in the activities of entrepreneurial universities;

3. The literature that analyze the case of one university in different countries.

In the first direction of the literature review, we shall analyze government documents and state policy relevant to the topic. Studying such researches is interesting as the analysis is general, the experience of a number of countries has to be studied and global trends and expected changes are reflected.

In the Communication from the Commission is outlined, that "As centres of knowledge, expertise and learning, higher education institutions can drive economic development in the 
territories where they are located" [23]. From the EENEE Analytical Report No. 18, Prepared for the European Commission we can read "Universities are encouraged to transfer their laboratory discoveries by patenting and licensing intellectual property to local firms. AUTM reported in 1999 that $82 \%$ of firms from university licenses operated in the state where the university was located... $71 \%$ of the entrepreneurs graduating from university start their business in the region where they were born. If the university was in the same region as they were born this probability increases to $87 \%$. Among those who moved to study at a university in another region, $51 \%$ start up the business in the same region as the university. The university thus serves as a strong magnet to start-ups by alumni and breaks the otherwise very strong "home bias" that entrepreneurs have" [24].

By OECD are presented "a selection of 20 entrepreneurship education and start-up support initiatives developed by universities or their core partners in eastern Germany, Finland, the UK, Poland, South Africa, and the US. They provide useful guidance and inspiration to those in universities that are seeking to support entrepreneurship and the policy makers that are behind them" [25].

University Industry Innovation Network [26] through its publication strived to support and stimulate the development of university-industry interaction, entrepreneurial universities and collaborative innovation. As every environment is different (e.g. country, culture, stage of development, type of institution) UIIN collected good practices on various subjects and levels from 29 countries.

Table 1 shows the literature covering the cases of several countries. Conclusions provided by them are more specific. They reflect the challenges, differences and similarities of the countries being on different levels of development from cross-cultural aspect.

Table 2 shows the literature about the experience of one entrepreneurial university in different countries. Such analysis is interesting as the experience of the university is studied in details and specific conclusions are drawn.

The cases discussed in Tables 1 and 2 are from different continents of the world. This substantiates that the process of changing the university model has actively begun everywhere and in the countries at any level of development.

In general, the number of spin-offs and the duration they function in the market is one of the indicators of efficient functioning of entrepreneurial universities. "University spin-offs have remarkably strengthened the linkage between universities and industry. The number of technology patents and spin-offs coming out of university research has a significant impact on regional economic and social development" [47]. In this context, it will be interesting to consider the views of many authors [48-56].

Thus, we can conclude that, the key factors affecting efficient functioning of entrepreneurial universities are: creating entrepreneurial environment, entrepreneurial staffs as well as entrepreneurial teaching and learning; a strong entrepreneurial vision and the presence of leaders; the need of an aware environment to support spin-off creation; identifying factors that determine continuous organizational success, etc. 
Table 1. Key findings of joint studies conducted by universities of several countries.

\begin{tabular}{|c|c|c|c|}
\hline $\begin{array}{l}\text { Refe- } \\
\text { rence }\end{array}$ & $\begin{array}{l}\text { Country/ } \\
\text { countries }\end{array}$ & $\begin{array}{l}\text { Number of } \\
\text { Countries/ } \\
\text { Universities }\end{array}$ & Key findings \\
\hline [27] & USA and UK & 2 universities & $\begin{array}{l}\text { an entrepreneurial university has the following five attributes: } \\
\text { 1. Top-down vision, strategy and leadership; } \\
\text { 2. Clearly defined entrepreneurship learning objectives that } \\
\text { drive the curriculum. } \\
\text { 3. Robust internal and external networks. } \\
\text { 4. A culture of innovation. } \\
\text { 5. Experiential learning and knowledge-transfer opportunities. }\end{array}$ \\
\hline [28] & $\begin{array}{l}\text { Austria and } \\
\text { Germany }\end{array}$ & 2 universities & $\begin{array}{l}\text { the lower level of founding intentions among students in } \\
\text { Munich and Vienna may be attributed to their less distinctive } \\
\text { entrepreneurship education. This leaves a great deal of room } \\
\text { for improvement [28]. }\end{array}$ \\
\hline [29] & $\begin{array}{l}\text { Italy, Norway, } \\
\text { and the United } \\
\text { Kingdom }\end{array}$ & 3 countries & $\begin{array}{l}\text { three countries adopting differing approaches to framework } \\
\text { conditions, to test whether national and university level } \\
\text { initiatives have an influence on the number of spin-offs created } \\
\text { and the quality of these spin-offs ... authors find that changes } \\
\text { in the institutional framework conditions at both levels are } \\
\text { conductive to the creation of more spin-offs, but that the } \\
\text { increase in quantity is at the expense of the quality of these } \\
\text { firms [29]. }\end{array}$ \\
\hline [30] & $\begin{array}{l}\text { Belgium, France, } \\
\text { Germany, } \\
\text { Switzerland, the } \\
\text { Netherlands, and } \\
\text { the United } \\
\text { Kingdom }\end{array}$ & $\begin{array}{c}16 \text { case } \\
\text { studies of } \\
\text { universities }\end{array}$ & $\begin{array}{l}\text { The article relies on } 16 \text { case studies of universities located in } \\
\text { six European countries in order to address the pros and cons } \\
\text { of the four types of TTOs. The results provide both a } \\
\text { conceptual understanding and an empirical overview of how } \\
\text { universities organize their technology transfer and intellectual } \\
\text { property management [30]. }\end{array}$ \\
\hline [31] & $\begin{array}{l}\text { Germany and } \\
\text { Poland }\end{array}$ & 2 countries & $\begin{array}{l}\text { This article explores the development of University-Business } \\
\text { Cooperation (UBC) both in Poland and in Germany, shining } \\
\text { a spotlight on the various factors influencing UBC, as well as } \\
\text { providing a comparison of the two countries [31]. }\end{array}$ \\
\hline [32] & $\begin{array}{l}\text { Spain and } \\
\text { Ireland }\end{array}$ & $\begin{array}{l}2 \text { countries } \\
\text { and } 4 \\
\text { universities }\end{array}$ & $\begin{array}{l}\text { Authors compare entrepreneurial universities in two European } \\
\text { regions (Spain and Ireland) using an in-depth qualitative } \\
\text { approach based on multiple case studies (two Spanish } \\
\text { universities and two Irish universities) between } 2006 \text { and } \\
\text { 2010. The findings provide organizational practices and } \\
\text { approaches relevant to the transformation process of other } \\
\text { regional universities seeking to become entrepreneurial [32]. }\end{array}$ \\
\hline [33] & $\begin{array}{l}\text { Chile and } \\
\text { Colombia }\end{array}$ & 2 universities & $\begin{array}{l}\text { Authors found that entrepreneurial education, the University } \\
\text { environment, and the prior entrepreneurial exposure are } \\
\text { mediated by the factors of the Ajzen`s model to generate } \\
\text { entrepreneurial intention in higher education students [33]. }\end{array}$ \\
\hline [34] & $\begin{array}{l}\text { Senegal and } \\
\text { Spain }\end{array}$ & 2 universities & $\begin{array}{l}\text { Findings indicate the existence of cultural differences } \\
\text { between both countries in the determination of } \\
\text { entrepreneurial intention. Spain showed personal attitude as } \\
\text { the main antecedent, whereas in Senegal, it was perceived } \\
\text { behavioral control [34]. }\end{array}$ \\
\hline
\end{tabular}


Table 2. Key findings of experience of one entrepreneurial university in different countries (continued on p.19).

\begin{tabular}{|c|c|c|c|}
\hline $\begin{array}{l}\text { Refe- } \\
\text { rence }\end{array}$ & Country & University & Key findings \\
\hline [35] & USA & MIT & $\begin{array}{l}\text { The article presents new possibilities for entrepreneurship } \\
\text { education from the ecosystem perspective. ...the results show } \\
\text { educational practices that go beyond the classical model of } \\
\text { classrooms, involving student-led activities, mentorship } \\
\text { programs, competitions, and others. Project-based courses, } \\
\text { experience-based activities and active-based activities are well } \\
\text { covered in the data presented [35]. }\end{array}$ \\
\hline [36] & USA & \begin{tabular}{|c|} 
University of \\
California, \\
Berkeley
\end{tabular} & $\begin{array}{l}\text {..the presence of leaders who marry strategic thinking and } \\
\text { capabilities development enhance the likelihood of a } \\
\text { university's competitive fitness and long-term survival [36]. }\end{array}$ \\
\hline [37] & Belgium & $\begin{array}{l}\text { Université } \\
\text { Libre de } \\
\text { Bruxelles }\end{array}$ & $\begin{array}{l}\text { The government at national and regional levels supports } \\
\text { universities. In all the Belgian regions, universities spin-offs } \\
\text { and science parks are funded through public funds and active } \\
\text { venture capital firms.... On the one hand, the need of an aware } \\
\text { environment to support spin-off creation and on the other the } \\
\text { need of the new firm to have resources from PRIs to build a } \\
\text { sustainable, competitive advantage [37]. }\end{array}$ \\
\hline [38] & Netherlands & $\begin{array}{l}\text { University } \\
\text { of Twente }\end{array}$ & $\begin{array}{l}\text {... a strong entrepreneurial vision and the adoption of a different } \\
\text { concept of knowledge may be the key for other small and peripheral } \\
\text { European universities, in order to reach both local economic } \\
\text { relevance and international excellence [38]. }\end{array}$ \\
\hline [39] & Italy & \begin{tabular}{|c|} 
ARCA \\
consortium \\
(University of \\
Palermo \\
incubator) \\
\end{tabular} & $\begin{array}{l}\text {...demonstrate that academic incubators play a key role in firm } \\
\text { viability [39]. }\end{array}$ \\
\hline [40] & Malaysia & \begin{tabular}{|c|} 
Universiti \\
Teknologi \\
MARA \\
\end{tabular} & $\begin{array}{l}\text {... discussed the efforts of the university in creating } \\
\text { entrepreneurial environment, entrepreneurial staffs as well as } \\
\text { entrepreneurial teaching and learning [40]. }\end{array}$ \\
\hline [41] & Sweden & $\begin{array}{l}\text { Chalmers } \\
\text { University of } \\
\text { Technology }\end{array}$ & $\begin{array}{l}\text {...the difficulties in creating the entrepreneurial university: } \\
\text { transparency; organisation of the infrastructure for } \\
\text { entrepreneurship; integration and the commercialization of the } \\
\text { research [41]. }\end{array}$ \\
\hline$[42]$ & Croatia & $\begin{array}{l}\text { J.J. } \\
\text { Strossmayer } \\
\text { University in } \\
\text { Osijek }\end{array}$ & $\begin{array}{l}\text { The lack of connections between individual ...components of } \\
\text { the model is the biggest obstacle to the emergence of } \\
\text { integrative and then entrepreneurial university. Each university } \\
\text { needs to find its own way to transform into entrepreneurial } \\
\text { university depending on the situation it is in, resources and } \\
\text { environment of the university [42]. }\end{array}$ \\
\hline [43] & $\begin{array}{l}\text { East } \\
\text { Africa, } \\
\text { Tanzania }\end{array}$ & $\begin{array}{l}\text { Iringa } \\
\text { University } \\
\text { College }\end{array}$ & $\begin{array}{l}\text { The results of the study show that it is possible to identify } \\
\text { factors that determine continuous organizational success in } \\
\text { Africa, and that managers can be offered a framework that adds } \\
\text { focus to improvement [43]. }\end{array}$ \\
\hline
\end{tabular}


Table 2. Key findings of experience of one entrepreneurial university in different countries (continuation from p.18).

\begin{tabular}{|c|c|c|c|}
\hline $\begin{array}{l}\text { Refe- } \\
\text { rence }\end{array}$ & Country & University & Key findings \\
\hline [44] & Canada & $\begin{array}{l}\text { University } \\
\text { of Waterloo }\end{array}$ & $\begin{array}{l}\text { Universities generate and disseminate knowledge as a common } \\
\text { good. Both of these functions co-exist at University of Waterloo. } \\
\text { Because the process of knowledge transfer into the local economic } \\
\text { community is multi-faceted, and largely person-embodied, } \\
\text { universities cannot be viewed is such a dualistic way [44]. }\end{array}$ \\
\hline [45] & China & $\begin{array}{l}\text { Northeastern } \\
\text { University in } \\
\text { China }\end{array}$ & $\begin{array}{l}\text { The pathway to an entrepreneurial university begins with } \\
\text { government pulled industry-university collaboration, to } \\
\text { university-industry collaboration p interaction Triple helix. } \\
\text { This may be followed by a gradually developing } \\
\text { "university-industry collaboration" in which companies fund } \\
\text { academic research with potential industrial use, the beginnings } \\
\text { of a University-pushed triple helix [45]. }\end{array}$ \\
\hline [46] & Indonesia & $\begin{array}{l}\text { Bogor } \\
\text { Agricultural } \\
\text { University }\end{array}$ & $\begin{array}{l}\text {... Explore university entrepreneurial transformation and } \\
\text { emphasized that the development of entrepreneurial activity, } \\
\text { learning and teaching processes need more attention [46]. }\end{array}$ \\
\hline
\end{tabular}

\section{THE ROLE OF ENTREPRENEURIAL UNIVERSITIES IN FORMATION OF AN ENTREPRENEURIAL ECOSYSTEM}

The World Economic Forum, in collaboration with Stanford University, Ernst \& Young and Endeavor, surveyed over 1000 entrepreneurs from around the globe and in 2014 introduced the Report "Around the Globe and Early-Stage Company Growth Dynamics - the Entrepreneur's Perspective". In this report, there are given eight pillars and components of an Entrepreneurial Ecosystem [57]. This model builds on the previous work on entrepreneurial ecosystems by EY, the OECD, and Professor Daniel Isenberg (see Exhibit 1).

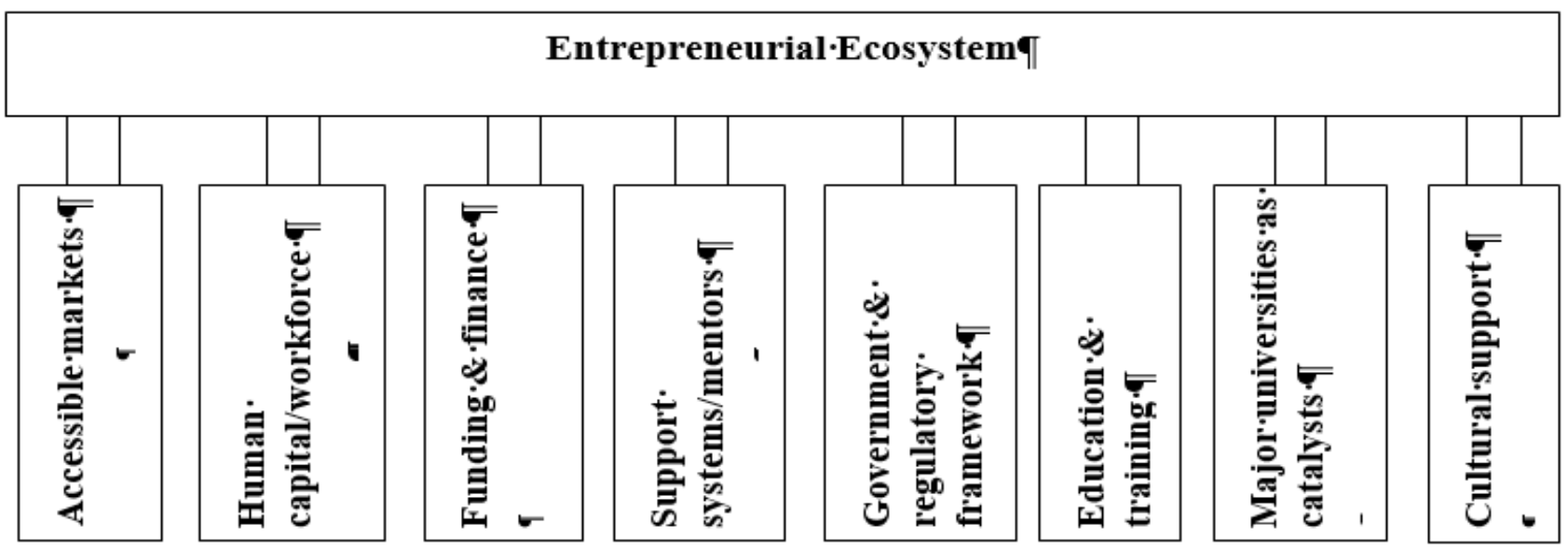

Figure 1. The eight pillars of an Entrepreneurial Ecosystem [57].

The pillars and components of an Entrepreneurial Ecosystem are [57]: 
- Accessible markets (Domestic market: Large companies as customers; Small/medium-sized companies as customers; Governments as customers. Foreign market: Large companies as customers; Small/medium-sized companies as customers; Governments as customers);

- Human capital/workforce (Management talent; Technical talent; Entrepreneurial company experience; Outsourcing availability; Access to immigrant workforce);

- Funding and finance (Friends and family; Angel investors; Private equity; Venture capital; Access to debt);

- Support systems/mentors (Mentors/advisers; Professional services; Incubators/accelerators; Network of entrepreneurial peers);

- Government and regulatory framework (Ease of starting a business; Tax incentives; Business-friendly legislation/policies; Access to basic infrastructure; Access to telecommunications/broadband; Access to transport);

- Education and training (Available workforce with pre-university education; Available workforce with university education; Entrepreneur-specific training);

- Major universities as catalysts (Promoting a culture of respect for entrepreneurship; Playing a key role in idea-formation for new companies; Playing a key role in providing graduates for new companies)

- Cultural support (Tolerance of risk and failure; Preference for self-employment; Success stories/role models; Research culture; Positive image of entrepreneurship; Celebration of innovation).

The three strongest pillars for Europe are human capital/workforce $(81 \%)$, accessible markets (72 \%) and education and training $(60 \%)$. The average percentages for ready availability across the eight pillars for region is on the first place by $86 \%$, US - Silicon Valley/Bay Area [57].

It should be noted that the entrepreneurial universities have direct positive impact on 5 components of the above 8 pillars. These components in the text are marked by the italic font. This opinion is strengthened by the fact that the region, where Stanford University is located, has the best indicator. This university is one of the most successful entrepreneurial universities in the world. Stanford alumni and faculty have created more than 39900 companies since the 1930s.

In 2017-2018 Stanford University received \$40,96 million in gross royalty revenue from 813 technologies. Fifty-three of the inventions generated $\$ 100,000$ or more in royalties. Seven inventions generated $\$ 1$ million or more. In 2017-18, the Office of Technology Licensing (OTL) concluded 150 new licenses. Stanford has 18 designated independent laboratories, centers and institutes that provide a physical and intellectual intersection between schools and disciplines.

Thus, we can conclude that entrepreneurial universities play the significant role in the formation of an entrepreneurial ecosystem.

On the other hand, we would like to discuss one more report "The Global Entrepreneurship Index 2018" by the Global Entrepreneurship and Development Institute (USA). According to this report a range of entrepreneurial framework conditions are: "government, research and development, education, infrastructure, financial sector and the corporate sector" [58]. Since entrepreneurial university combines education, research and business in one space and has an effective dialogue with the local government; we can conclude that entrepreneurial universities improve the entrepreneurial framework, too. 


\section{ENTREPRENEURIAL UNIVERSITY - CORE SYSTEM FOR THE INNOVATIVE DEVELOPMENT OF ECONOMY}

The turbulence of the economy brings about new demands on higher education systems across the world. In such environment of development, universities, and in particular entrepreneurial universities, play a significant role.

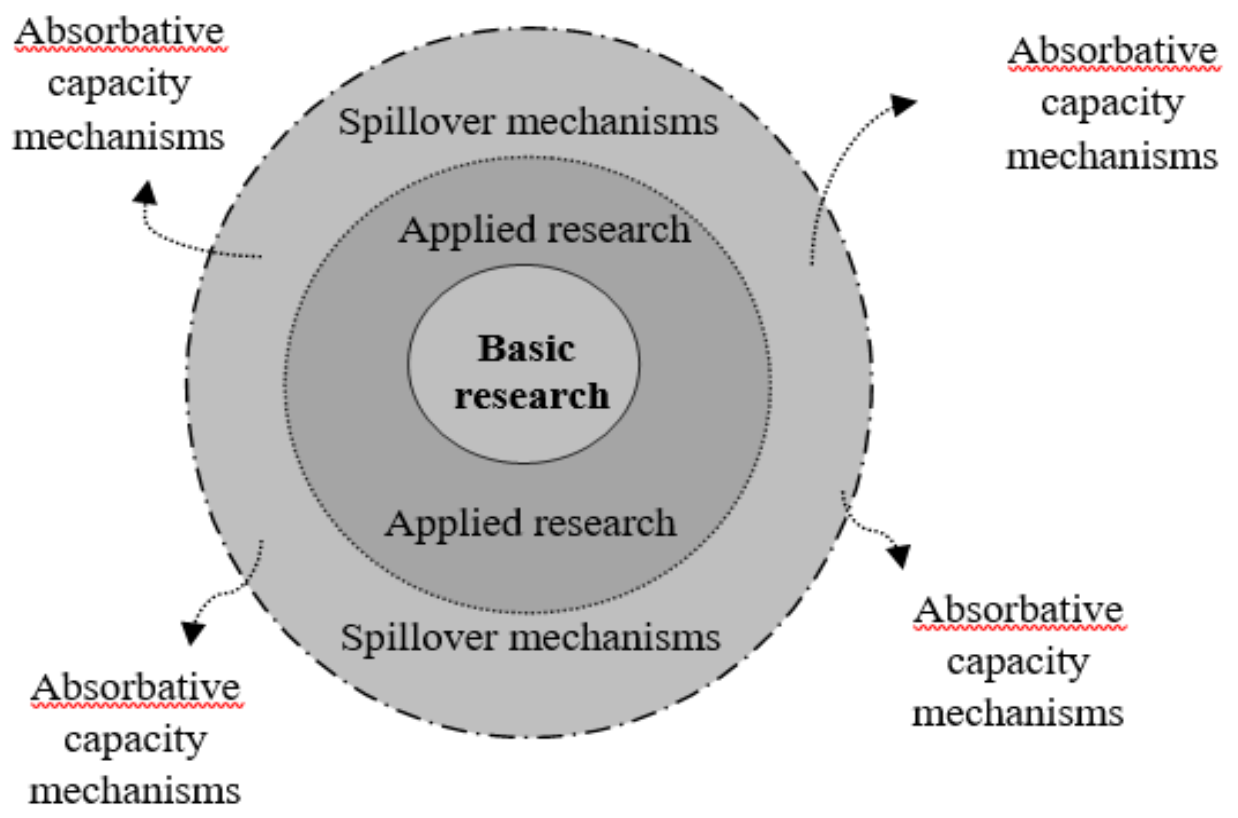

Figure 2. The entrepreneurial university [10].

The entrepreneurial university model is presented in Figure 1. Figure 1 shows that basic and applied research carried out at the universities requires "Third ring", which consists of mechanisms to facilitate the spillover of knowledge from the research core and applied programs generating that knowledge to society where that knowledge would be commercialized or at least applied [10].

The outcomes of effective formation of "University-Industry-Government" (The Triple Helix) relations are the patents illustrated in Figure 2. Creation of patents in the university environment will provide businesses with the workforce equipped with all the necessary skills. The new knowledge rapidly flows into education and leads to the inspiration of new ideas.

According to Leydesdorff "patents are considered as positioned in terms of the three social coordination mechanisms of (1) wealth generation on the market by industry, (2) legislative control by government, and (3) novelty production in academia. Whereas patents are output indicators for science and technology, they function as input into the economy" [59]. The above factors make it clear that by creating patents entrepreneurial universities serve as a core system and source for the innovative development of Economy [60].

Figure 3 demonstrates the systemic impact of the entrepreneurial university on the innovative development of economy. The invention patented at entrepreneurial universities improves the possibility of starting a new business and /or functioning of existing business (this process is shown with dashed line n Figure 3). As a result, the culture of investing in research and development 


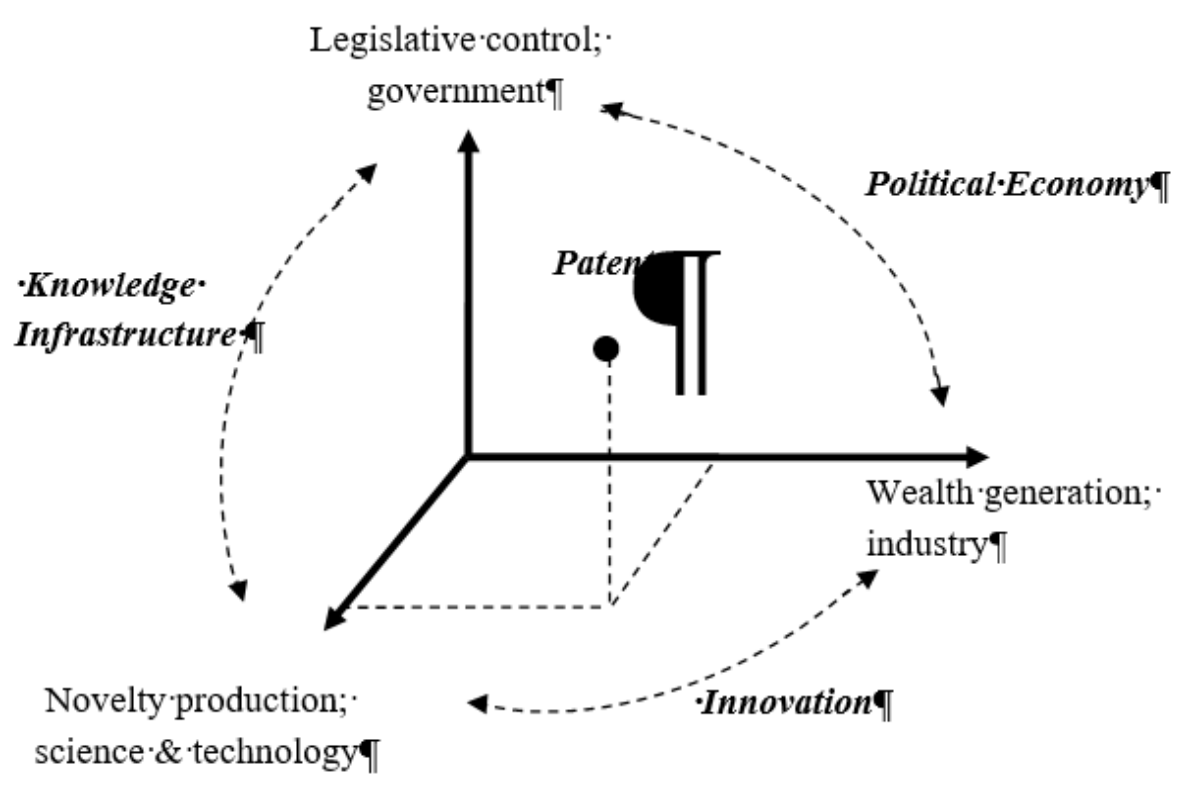

Figure 3. Patents as events in the three-dimensional space of Triple Helix interactions [59].

is gradually developed among the business organizations. They constantly try to have links with the universities and focus on innovative development (this process is shown with green dashed lines on Figure 3). Here emerges a new wave of activities finally resulting in Trademark and Patent applications.

The interests of economic development make the government allocate funds for research that is helpful for both business and universities. Under such circumstances, the time required to achieve government goals is shorter than with standard policy, as incentive measures can introduced simultaneously in many areas through the university-industry-government triple helix. "This allows direct dialogue on education, science, and business in one area, making it possible to combine private and public funds to encourage the formation of new firms, with the assistance of incubators and spin-offs to provide a properly trained workforce needed by businesses to conduct intense research and other activities" [61]. These processes promote formation of the system in which entrepreneurial university ensures innovative development of the economy.

The entrepreneurial universities create a sort of micro-system around themselves and form a cluster after a certain period.

Why this is system? The relation, given in Figure 3, has all the features characteristic of the system among entrepreneurial university and the economy, features that have been described in the works of other authors. For the purposes of this article, we provide a definition based on Ackoff's suggestion that "a system is a set of two or more interrelated elements with the following properties:

1. Each element has an effect on the functioning of the whole.

2. Each element is affected by at least one other element in the system.

3. All possible subgroups of elements also have the first two properties" [62]. Each part of the model in Figure 3 meets all these characteristics of a system.

Systemic links, as shown in Figure 3, might not be visible in the standard approach or the study of entrepreneurial universities. Thus, the real potential systemic links cannot be identified. 


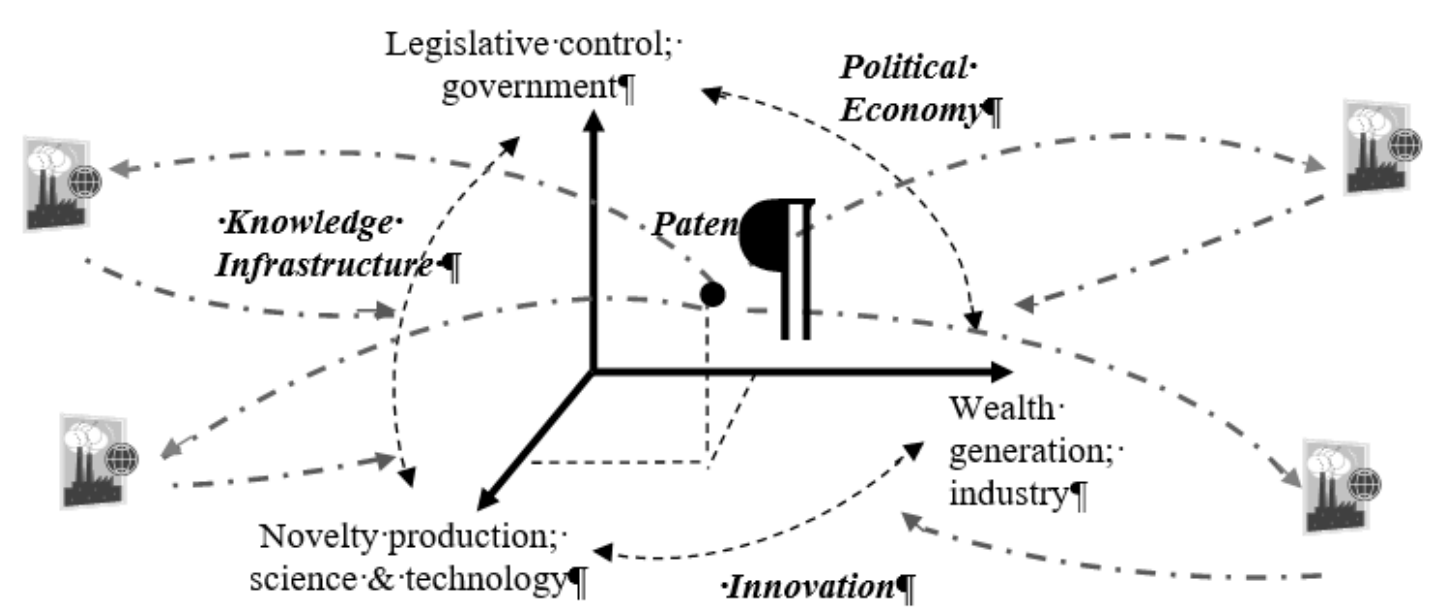

Figure 4. Patents - output indicators for science and technology and input into the economy (developed by Gagnidze based on [59]).

\section{ENTREPRENEURIAL UNIVERSITY - ONE OF THE TOOLS FOR THE CHALLENGES OF THE $4^{\mathrm{TH}}$ INDUSTRIAL REVOLUTION}

The World Economic Forum is introducing the new Global Competitiveness Index 4,0 as a much-needed economic compass, building on forty years of experience of benchmarking the drivers of long-term competitiveness and integrating the latest learnings about the factors of future productivity.

Table 3 presents the data of the old [63] and new [64] World Economic Forum reports for the $12^{\text {th }}$ pillar. In the new Global Competitiveness Index 4,0 this Pillar includes 10 indicators (instead of previous 7). It is obvious that improvement of 9 out of these 10 indicators is supported by effective functioning of entrepreneurial universities. Due to this, the need for rethinking of the university system is one of the challenges of the modern education system. This process has actively started in developed and developing countries.

It should be noted that Schwab and Zahidi [65] identified "10 things you - and your government should know about competitiveness in the Fourth Industrial Revolution", namely:

1. "Competitiveness is not a luxury good;

2. Investing in people is good for social and economic outcomes;

3. Embracing globalization in the 4IR goes beyond free trade;

4. But open economies must also embrace social protection;

5. Creating an innovation ecosystem goes well beyond research and development;

6. Technology offers a path to economic leapfrogging but only in combination with other factors;

7. Institutions still matter;

8. As do infrastructure and the financial system;

9. In a time of constant change, there is a need for constant agility;

10. Achieving equality, sustainability and growth together is possible - but needs proactive, far-sighted leadership" [65].

The authors have also provided detailed explanation of each advice. This explanation makes it clear that entrepreneurial universities can have direct positive impact on the implementation of 7 of these 10 
Table 3. Data of the sub-pillars of Innovation (capability) in the 2016-2018 Global Competitiveness reports of the World Economic Forum.

\begin{tabular}{|l|l|c|l|}
\hline \multicolumn{1}{|c|}{ G } & \multicolumn{1}{|c|}{ GCR 2016-2017 } & $\#$ & \multicolumn{1}{c|}{ GCR 2018 } \\
\hline 12.01 & 12th pillar: Innovation & & 12th pillar: Innovation capability \\
\hline 12.02 & $\begin{array}{l}\text { Quality of scientific research } \\
\text { institutions }\end{array}$ & 12.01 & Diversity of workforce \\
\hline 12.03 & Company spending on R\&D & 12.03 & State of cluster development \\
\hline 12.04 & $\begin{array}{l}\text { University-industry collaboration } \\
\text { in R\&D }\end{array}$ & 12.04 & Multi-stakeholder collaboration \\
\hline 12.05 & $\begin{array}{l}\text { Government procurement of } \\
\text { advanced tech. products }\end{array}$ & 12.05 & Scientific publications H Index \\
\hline 12.06 & $\begin{array}{l}\text { Availability of scientists and } \\
\text { engineers }\end{array}$ & 12.06 & Patent applications \\
\hline 12.07 & PCT patent applications & 12.07 & R\&D expenditures \\
\hline- & - & 12.08 & Quality of research institutions \\
\hline- & - & 12.09 & Buyer sophistication \\
\hline- & - & 12.10 & Trademark applications \\
\hline
\end{tabular}

advices. Consequently, we can conclude that the model of entrepreneurial universities is effective and transition to this model is very essential in terms of expected $4^{\text {th }}$ industrial revolution.

In general, the role of education is directly or indirectly critical in the leap-like development and it will continue to remain the same during the digital era.

\section{CONCLUSION}

In the nearest 5-10 years, the world economy will face a period of sharp changes predicted by recognized research organizations. This process is called the Fourth Industrial Revolution and is evaluated in two ways. On the one hand, the expected threats (disappearance of many jobs) are discussed and on the other hand, the expected opportunities (the emergence of many new professions) are evaluated. In addition, over half of those employed will need reskilling and upskilling.

The above-mentioned facts put on the agenda the necessity of finding the tools, which can be used to mitigate the potential challenges and apply to new opportunities. We consider entrepreneurial universities as one of these tools. These universities create an entrepreneurial ecosystem and develop the local economy. After a certain period the entrepreneurial universities create a sort of micro-system around themselves and form a cluster.

The literature review in the current article revealed the main difficulties that are associated with changing the university model and the activities of the third generation universities in different countries. We have developed the schemes created by prominent scholars and schematically showed the systemic role of universities in the development of local economy.

Thus, upon the studies provided by the world-renowned organizations, the ideas of well-known scholars and the example of the best practices from the various countries, we can conclude that Entrepreneurial University model is effective and leads to the innovative consequences in digital era. At the same time it should be noted that to move the University development at this level will require significant efforts. 
The key factors affecting efficient functioning of entrepreneurial universities are: creating entrepreneurial environment, entrepreneurial staffs as well as entrepreneurial teaching and learning; a strong entrepreneurial vision and the presence of leaders; the need of an aware environment to support spin-off creation; identifying factors that determine continuous organizational success, etc.

The article is partly limited as it is a desk research. It does not include research on new methods of teaching, which is desirable to develop in HEIs. These issues were beyond our scope but are nonetheless very interesting. Our future research will therefore move towards these topics.

\section{REFERENCES}

[1] Schwab, K.: The Global Competitiveness Report 2018.

World Economic Forum, Geneva, 2018, http://www3.weforum.org/docs/GCR2018/05FullReport/TheGlobalCompetitivenessReport2018.pdf, accessed $23^{\text {th }}$ November 2019,

[2] Centre for the New Economy and Society: The Future of Jobs Report 2018.

World Economic Forum, Geneva, 2018, http://www3.weforum.org/docs/WEF Future of Jobs 2018.pdf, accessed $24^{\text {th }}$ November 2019,

[3] World Economic Forum: Globalization 4.0 Shaping a New Global Architecture in the Age of the Fourth Industrial Revolution.

World Economic Forum, Geneva, 2019, http://www3.weforum.org/docs/WEF_Globalization_4.0_Call_for_Engagement.pdf, accessed $24^{\text {th }}$ November 2019,

[4] World Economic Forum: The Future of Jobs: Employment, Skills and Workforce Strategy for the Fourth Industrial Revolution.

World Economic Forum, Geneva, 2016, http://www3.weforum.org/docs/WEF Future of Jobs.pdf, accessed $23^{\text {th }}$ November 2019,

[5] Manyika, J. et al.: Jobs lost, jobs gained: Workforce transitions in a time of automation. McKinsey Global Institute, Amsterdam, 2017, https://www.mckinsey.com/ /media/McKinsey/Featured\%20Insights/Future\%20of\%20Organization s/What $\% 20$ the $\% 20$ future $\% 20$ of $\% 20$ work $\% 20$ will $\% 20$ mean $\% 20$ for $\% 20$ jobs $\% 20$ skills $\% 20$ and $\% 20 \mathrm{w}$ ages/MGI-Jobs-Lost-Jobs-Gained-Report-December-6-2017.ashx, accessed $24^{\text {th }}$ November 2019,

[6] Daheim, C. and Wintermann, O.: 2050: The Future of Work.

Findings of an International Delphi Study of The Millennium Project, 2016, https://www.bertelsmann-stiftung.de/fileadmin/files/BSt/Publikationen/GrauePublikationen/BST_De 1phi_E_03lay.pdf, accessed $24^{\text {th }}$ November 2019,

[7] Desire2learn (D2L): The Future of work and Learning In the Age of the $4^{\text {th }}$ Industrial Revolution.

https://www.d21.com/wp-content/uploads/2018/01/The-Future-of-Work-and-Learning-D2L.pdf, accessed $24^{\text {th }}$ November 2019,

[8] Etzkowitz, H. and Leydesdorff, L.: The Dynamics of Innovation: From National Systems and "Mode 2" to a Triple Helix of University-Industry-Government Relations.

Research Policy 29(2), 109-123, 2000, http://dx.doi.org/10.1016/S0048-7333(99)00055-4,

[9] OECD: A Guiding Framework for Entrepreneurial Universities. European Commission, Better policies for better lives, 2012, https://www.oecd.org/site/cfecpr/EC-OECD\%20Entrepreneurial\%20Universities\%20Framework.pdf, accessed $24^{\text {th }}$ November 2019 , 
[10] Audretsch, D.B.: From the entrepreneurial university to the university for the entrepreneurial society.

Journal of Technology Transfer 39(3), 313-321, 2014, http://dx.doi.org/10.1111/phen.12077,

[11] Berggren, E.: Researchers as enablers of commercialization at an entrepreneurial university. Journal of Management Development 36(2), 217-232, 2017, http://dx.doi.org/10.1108/JMD-06-2016-0117,

[12] Di Fatta, D.; Caputo, F. and Dominici, G.: A relational view of start-up firms inside an incubator: the case of the ARCA consortium.

European Journal of Innovation Management 21(4), 601-619, 2018, http://dx.doi.org/10.1108/EJIM-08-2017-0110,

[13] Etzkowitz, H. and Zhou, Ch.: Introduction to special issue Building the entrepreneurial university: a global perspective.

Science and Public Policy 35(9), 627-635, 2008, http://dx.doi.org/10.3152/030234208X363178,

[14] Farsi, J.Y.; Imanipoir, N. and Salamzadeh, A.: Entrepreneurial University Conceptualization: Case of Developing Countries.

International Journal Global Business and Management Research (GBMR) 4(2), 193-204, 2012,

[15] Gagnidze, I.: The Role of International Educational and Science Programs for Sustainable Development (Systemic Approach).

Kybernetes 47(2), 409-424, 2018, http://dx.doi.org/10.1108/K-03-2017-0114,

[16] Gogorishvili, I.; Gagnidze, I. and Papachashvili, N.: Innovative Approaches in Higher Education System.

$6^{\text {th }}$ Business Systems Laboratory International Symposium “Borders without Borders”, Pavia, Italy, Ab.56, 2019, http://bslab-symposium.net/Pavia-2019/BSLAB-\%20Book\%20of\%20Abstract-Pavia-2019.pdf\#page $=214$, accessed $24^{\text {th }}$ November 2019 ,

[17] Hsu, D.H.; Roberts, E.R. and Easley Ch.E.: Entrepreneurs from technology-based universities: Evidence from MIT.

Research Policy 36(5), 768-788, 2007, https://econpapers.repec.org/article/eeerespol/v 3a36 3ay 3a2007 3ai 3a5 3ap 3a768-788.htm, accessed $24^{\text {th }}$ November 2019,

[18] Muscio, A. and Pozzali, A.: The effects of cognitive distance in university-industry collaborations: some evidence from Italian universities.

The Journal of Technology Transfer 38(4), 486-508, 2013, http://dx.doi.org/10.1007/s10961-012-9262-y,

[19] Rasmussen, E. and Wright, M.: How can universities facilitate academic spin-offs? An entrepreneurial competency perspective.

The Journal of Technology Transfer 40(5), 782-799, 2015, http://dx.doi.org/10.1007/s10961-014-9386-3,

[20] Sharif, N. and Baark, E.: Mobilizing technology transfer from university to industry, The experience of Hong Kong universities.

Journal of Technology Management in China 3(1), 47-65, 2008, http://dx.doi.org/10.1108/17468770810851494,

[21] Sperrer, M.; Muller, Ch. and Soos, J.: The Concept of the Entrepreneurial University Applied to Universities of Technology in Austria: Already Reality or a Vision of the Future? Technology Innovation Management Review 6(10), 37-44, 2016, http://dx.doi.org/10.22215/timreview1026, 
[22] Walshok, M.L. and Shapiro, J.D.: Beyond Tech Transfer: A More Comprehensive Approach to Measuring the Entrepreneurial University.

https://extension.ucsd.edu/UCSDExtension/media/UCSDExtensionsMedia/community-and-research Icenter-for-research/Beyond-Tech-Transfer.pdf, accessed $24^{\text {th }}$ November 2019,

[23] European Commission: Communication from the Commission to the European Parliament, the Council, the European Economic and Social Committee and the committee of the Regions. Supporting growth and jobs - an agenda for the modernisation of Europe's higher education systems.

http://eur-lex.europa.eu/legal-content/EN/TXT/PDF/?uri=CELEX:52011DC0567\&from=EN, accessed $24^{\text {th }}$ November 2019,

[24] Veugelers, R. and Rey, E.: The contribution of universities to innovation, (regional) growth and employment.

European Expert Network on Economics of Education (EENEE) 18, 2014, http://www.eenee.de/eeneeHome/EENEE/Analytical-Reports.html, accessed $24^{\text {th }}$ November 2019 ,

[25] OECD: Universities, innovation and entrepreneurship criteria and examples of good practice. https://www.oecd.org/cfe/leed/43201452.pdf, accessed $24^{\text {th }}$ November 2019,

[26] Meerman, A. and Kliewe, T.: UIIN Good Practice Series 2014 - Fostering UniversityIndustry Relationships, Entrepreneurial Universities and Collaborative Innovation.

University Industry Innovation Network, Amsterdam, 2014,

[27] Meyers, A.D. and Pruthi, S.: Academic entrepreneurship, entrepreneurial universities and biotechnology.

Journal of Commercial Biotechnology 17(4), 349-357, 2011,

http://dx.doi.org/10.1057/jcb.2011.22,

[28] Franke, N. and Luthje, Ch.: Entrepreneurial Intentions of Business Students - A Benchmarking Study.

International Journal of Innovation and Technology Management 1(3), 269-288, 2004, http://dx.doi.org/10.1142/S0219877004000209,

[29] Fini, R.; Fu, K.; Mathisen, M.T.; Rasmussen, E. and Wright, M.: Institutional determinants of university spin-off quantity and quality: A longitudinal, multilevel, cross-country study.

Small Business Economics 48(2), 361-391, 2017, http://dx.doi.org/10.1007/s11187-016-9779-9,

[30] Schoen, A.; Potterie, B.P. and Henkel, J.: Governance typology of universities' technology transfer processes.

The Journal of Technology Transfer 39(3), 435-453, 2014, http://dx.doi.org/10.1007/s10961-012-9289-0,

[31] Baaken, Th.; Rossano, S.; Von Hagen, F.; Todd, D. and Arno, M.: University-Business Cooperation and Entrepreneurship at Universities - An Empirical Based Comparison of Poland and Germany.

Optimum. Studia ekonomiczne 5(77), 3-26, 2015, http://dx.doi.org/10.15290/ose.2015.05.77.01,

[32] Guerrero, M.; Urbano, D.; Cunningham, J. and Organ, D.: Entrepreneurial universities in two European regions: a case study comparison.

The Journal of Technology Transfer 39(3), 415-434, 2014, http://dx.doi.org/10.1007/s10961-012-9287-2,

[33] Soria-Barreto, K., et al.: Prior Exposure and Educational Environment towards Entrepreneurial Intention.

Journal of Technology Management \& Innovation 12(2), 45-58, 2017, http://dx.doi.org/10.4067/S0718-27242017000200006, 
[34] García-Rodríguez, F.; Gil-Soto E.; Ruiz-Rosa, I. and Sene, P.M.: Entrepreneurial intentions in diverse development contexts: a cross-cultural comparison between Senegal and Spain.

International Entrepreneurship and Management Journal 11(3), 511-527, 2015, http://dx.doi.org/10.1007/s11365-013-0291-2,

[35] Riberio, A.T.V.B.; Uechi, J.N. and Plonski, G.A.: Building builders: entrepreneurship education from an ecosystem perspective at MIT.

Triple Helix, Springer Open 5(3), 1-20, 2018, http://dx.doi.org/10.1186/s40604-018-0051-y,

[36] Leih, S. and Teece, D.: Campus Leadership and the Entrepreneurial University: A Dynamic Capabilities Perspective.

Academy of Management Executive 30(2), 182-210, 2016, http://dx.doi.org/10.5465/amp.2015.0022,

[37] Caiazza, R.: Factors affecting spin-off creation: Macro, meso and micro level analysis. Journal of Enterprising Communities: People and Places in the Global Economy 8(2), 103-110, 2014, http://dx.doi.org/10.1108/JEC-12-2012-0061,

[38] Lazzeretti, L. and Tavoletti, E.: Higher Education Excellence and Local Economic Development: The Case of the Entrepreneurial University of Twente.

European Planning Studies 13(3), 475-493, 2005, http://dx.doi.org/10.1080/09654310500089779,

[39] Dominici, G. and Levanti, G.: The incubation process for the creation of viable firms: The case of ARCA Consortium.

International Journal Markets and Business Systems 1(1), 4-27, 2015, http://dx.doi.org/10.1504/IJMABS.2015.070262,

[40] Rahim, H.L., et al.:Entrepreneurial University: A Case of Universiti Teknologi MARA. International Academic Research Journal of Social Science 1(2), 224-231, 2015,

[41] Jacob, M.; Lundqvist, M., and Hellsmark, H.: Entrepreneurial transformations in the Swedish University system: the case of Chalmers University of Technology.

Research Policy 32(9), 1555-1568, 2003, http://dx.doi.org/10.1016/S0048-7333(03)00024-6,

[42] Peterka, S.O. and Salihovic, V.: What is entrepreneurial university and why we need it? Economy of Eastern Croatia: Yesterday, Today, Tomorrow 1(1), 98-107, 2012, http://dx.doi.org/10.1057/978-1-349-95121-5 2934-1,

[43] Waal, A. and Chachage, B.: Applicability of the high-performance organization framework at an East African university The case of Iringa University College.

International Journal of Emerging Markets 6(2), 148-167, 2011, http://dx.doi.org/10.1108/17468801111119506,

[44] Bramwell, A. and Wolfe, D.A.: Universities and Regional Economic Development: The Entrepreneurial University of Waterloo.

Paper presented at Canadian Political Science Association (CPSA) Annual Conference, The University of Western Ontario London, London, 2005, https://www.cpsa-acsp.ca/papers-2005/Bramwell.pdf, accessed $24^{\text {th }}$ November 2019,

[45] Zhou, Ch.: Emergence of the entrepreneurial university in evolution of the triple helix: The case of Northeastern University in China.

Journal of Technology Management in China 3(1), 109-126, 2008, http://dx.doi.org/10.1108/17468770810851539,

[46] Mudde, H.L.M.; Widhiani, A.P. and Fauzi, A.M.: Entrepreneurial University Transformation in Indonesia: A Comprehensive Assessment of IPB.

Journal on Business Review (GBR) 5(1), 46-61, 2017, http://dx.doi.org/10.1016/j.intell.2017.01.001, 
[47] Pattnaik, P.N., and Pandey, S.C.: University Spinoffs: What, Why, and How?

Technology Innovation Management Review 4(12), 44-50, 2014, http://doi.org/10.22215/timreview/857,

[48] Bak, K.: Academic Entrepreneurship - Conceptual Framework and Example from Poland. Forum Scientiae Oeconomia 4(3), 105-114, 2016,

[49] Bakouros, Y.L. and Samara, E.T.: Academic Liaison Offices vs. Technology Transfer Units: Could they form a new joint mechanism towards the exploration of Academic/Research results? International Journal of Innovation Science 2(4),145-157, 2010, http://dx.doi.org/10.1260/1757-2223.2.4.145,

[50] Beraza-Garmendia, J.M. and Rodríguez-Castellanos, A.: Characteristics and effectiveness of university spin-off support programmes.

Academia Revista Latinoamericana de Administración 28(1), 14-44, 2015, http://dx.doi.org/10.1108/ARLA-09-2013-0139,

[51] Berbegal-Mirabent, J.; Sabaté, F. and Cañabate, A.: Brokering knowledge from universities to the marketplace: The role of knowledge transfer offices.

Management Decision 50(7), 1285-1307, 2012, http://dx.doi.org/10.1108/00251741211247012,

[52] Corsi, Ch., et al.: The effect of parent university on firm growth: an analysis of the Spanish and Italian USOs.

Journal of Management Development 36(2), 233-249, 2017, http://dx.doi.org/10.1108/JMD-06-2016-0108,

[53] Gagnidze, I. and Dominici, G.: Effectiveness of an Entrepreneurial Universities and Spin-offs: Experiences and Challenges.

$6^{\text {th }}$ Business Systems Laboratory International Symposium Borders without Borders. Pavia, Ab.61, 2019, http://bslab-symposium.net/Pavia-2019/BSLAB-\%20Book\%20of\%20Abstract-Pavia-2019.pdf\#page $=234$, accessed $24^{\text {th }}$ November 2019,

[54] Gübeli, M.H. and Doloreux, D.: An empirical study of university spin-off development. European Journal of Innovation Management 8(3), 269-282, 2005, http://dx.doi.org/10.1108/14601060510610153,

[55] Sciarelli, M.; Landi, G.; Turriziani, L. and Tani, M.: Diversity Management in Academic Business Venturing: Empirical Evidences from Italian Universities.

International Journal of Academic Research in Business and Social Sciences 9(3), 43-62, 2019, http://dx.doi.org/10.6007/IJARBSS/v9-i3/5627,

[56] Vesperi, W. and Gagnidze, I.: Rethinking the university system: Toward the entrepreneurial university (The case of Italy).

Kybernetes, 2019, http://dx.doi.org/10.1108/K-12-2018-0662,

[57] World Economic Forum: Around the Globe and Early-Stage Company Growth Dynamics the Entrepreneur's Perspective.

World Economic Forum, Geneva, 2014, http://reports.weforum.org/entrepreneurial-ecosystems-around-the-globe-and-early-stage-companygrowth-dynamics/wp-content/blogs.dir/34/mp/files/pages/files/nme-entrepreneurship-report-jan-82014.pdf, accessed $24^{\text {th }}$ November 2019,

[58] Ács Z.J.; Szerb, L. and Lloyd, A.: The Global Entrepreneurship Index, 2018. Global Entrepreneurship and Development Institute, Washington, D.C., 2017, http://dx.doi.org/10.1007/978-3-030-03279-1 3,

[59] Leydesdorff, L.: The Triple Helix of University-Industry-Government Relations. In: Carayannis, E. and Campbell, D.: Encyclopedia of Creativity, Innovation, and Entrepreneurship. Springer, New York, 2012, 
[60] Gagnidze, I.: Entrepreneurial University - core system for the innovative development of Economy.

Innovative Methodologies: International Art \& Science Conference, Academy of Dramatic Art, Zagreb, pp.35-38, 9-11 April 2019,

[61] Gagnidze, I.: From clusters to entrepreneurial universities and vice versa: ways of developing the local economy: a systemic approach.

International Journal of Markets and Business Systems 3(2), 181-196, 2018, http://dx.doi.org/10.1504/IJMABS.2018.10011650,

[62] Ackoff, R.L.: Creating the corporate future.

John Wiley, New York, 1981,

[63] Schwab, K.: World Economic Forum: The Global Competitiveness Report 2016-2017.

World Economic Forum, Geneva, 2016,

http://www3.weforum.org/docs/GCR2016-2017/05FullReport/TheGlobalCompetitivenessReport201 6-2017_FINAL.pdf, accessed $24^{\text {th }}$ November 2019,

[64] Schwab, K.: The Global Competitiveness Report 2018.

World Economic Forum, Geneva, 2018, http://www3.weforum.org/docs/GCR2018/05FullReport/TheGlobalCompetitivenessReport2018.pdf, accessed $24^{\text {th }}$ November 2019 ,

[65] Schwab, K. and Zahidi, S.: 10 things you-and your government-should know about competitiveness in the Fourth Industrial Revolution.

World Economic Forum, 2018,

https://www.weforum.org/agenda/2018/10/10-things-you-and-your-government-should-know-aboutcompetitiveness-in-the-fourth-industrial-revolution/?fbclid=IwAR031UxBa6yn901YqITjS4bWMyC hUoop2KjYZYjOeHSqOoJAkB123grOwoQ, accessed 24 ${ }^{\text {th }}$ November 2019. 